\title{
Influence of Carbon Content of WC-Co Electrode Materials on the Wear Resistance of Electrospark Coatings
}

\author{
Alexander A. Burkov*, Sergey A. Pyachin, Alexey V. Zaytsev \\ Institute of Materials, Khabarovsk Scientific Centre, Far East Branch, Russian Academy of Sciences, Khabarovsk, Russia. \\ Email: "burkovalex@mail.ru
}

Received January $24^{\text {th }}, 2012$; revised February $17^{\text {th }}, 2012$; accepted March $5^{\text {th }}, 2012$

\begin{abstract}
In the electrospark deposition (ESD) of WC-Co materials on low carbon steel, tungsten carbide (WC) decarburization is observed. The use of an inert atmosphere (argon) does not eliminate the problem of tungsten carbide decarburization during electrospark processing. The effect of the carbon concentration of electrode materials on the phase composition and mechanical properties of WC (10 wt $\%$ of Co) ESD coatings has been investigated in this work. The introduction of additional carbon (graphite) in the electrode material on the basis of the WC-10\%Co leads to an increased amount of $\mathrm{WC}$ in the obtained coatings and thus improves their wear resistance.
\end{abstract}

Keywords: Hard Coating; Electrospark Deposition; Tungsten Carbide; Wear

\section{Introduction}

WC-Co alloys are widely used as electrode materials to deposit hardening coatings on metals by electrospark alloying [1-4]. However, it is known that the tungsten carbide (WC) decomposes to $\mathrm{W}_{2} \mathrm{C}$ and tungsten under the discharge action, and therefore the composition of the coating is different from the initial composition of the treating electrode, that is, the anode [5-7]. The decarburization of tungsten carbide reduces the wear resistance of coatings. With increasing power evolving at discharges, the $\mathrm{W}_{2} \mathrm{C}$ carbide content of the deposited coating increases [5]. We previously established that the use of a high discharge frequency $(1 \mathrm{kHz})$ and small pulse duration (less than $20 \mu \mathrm{s}$ ) did not have a significant effect [8]. If argon is applied as a protective environment for the electrospark processing, the degradation of the tungsten carbide WC decreases but only by a negligible amount.

The most investigated electrode material is the $90 \%$ WC- $10 \%$ Co alloy, whose use allows a coating with advanced wear resistance to be created. In our work, electrode materials based on tungsten carbide and cobalt with different additions of carbon were sintered and the properties of the corresponding electrospark coatings were studied. One of the major aims of these examinations was to determine the effect of the carbon concentration of the electrode material on the decomposition of tungsten carbide during the electrospark process.

*Corresponding author.

\section{Material and Methods}

\subsection{Electrode Materials}

The standard technology for hard alloys was used to create electrodes [9]. First, all powder mixtures of W, Co, and $\mathrm{C}$ were prepared so that the cobalt content was constant $(10 \mathrm{wt} \%)$ and the carbon concentration was varied $(1.5,2.5,3.5,4.5,5.5,8$ and $10 \mathrm{wt} \%)$ (Table 1).

Then, the powder mixtures were mixed by a PM400 planetary ball mill (Germany) at a rotational velocity of $250 \mathrm{rpm}$ during $30 \mathrm{~min}$ with the addition of $5 \mathrm{ml}$ of isopropyl alcohol. The obtained powders were mixed with a solution of rubber in gasoline and then pressed using a Test Press-250 M (Russia) with a load of $30 \mathrm{kN}$. The masses of samples made for the sintering were identical and equalled $13 \mathrm{~g}$. The pressed mixtures were sintered in a Carbolite STF vacuum tube oven (England) at $1400^{\circ} \mathrm{C}$ during $8 \mathrm{~h}$. The hard alloy sticks used as electrodes had sizes of $40 \times 5 \times 5 \mathrm{~mm}^{3}$. The mass losses of sintered

Table 1. Designations of electrodes.

\begin{tabular}{ccc}
\hline \multirow{2}{*}{ Source anode composition $(\mathrm{wt} \%)$} & \multicolumn{2}{c}{ Designation } \\
\cline { 2 - 3 } & Anode & Cathode \\
\hline W-10\%Co-1.5\%C & $1.5 \mathrm{~A}$ & $1.5 \mathrm{C}$ \\
W-10\%Co- $2.5 \% \mathrm{C}$ & $2.5 \mathrm{~A}$ & $2.5 \mathrm{C}$ \\
W-10\%Co-3.5\%C & $3.5 \mathrm{~A}$ & $3.5 \mathrm{C}$ \\
W-10\%Co-4.5\%C & $4.5 \mathrm{~A}$ & $4.5 \mathrm{C}$ \\
W-10\%Co-5.5\%C & $5.5 \mathrm{~A}$ & $5.5 \mathrm{C}$ \\
W-10\%Co- $8 \% \mathrm{C}$ & $8 \mathrm{~A}$ & $8 \mathrm{C}$ \\
W-10\%Co- $10 \% \mathrm{C}$ & $10 \mathrm{~A}$ & $10 \mathrm{C}$ \\
\hline
\end{tabular}


samples (which were induced by the plasticizer evaporation and burning out of carbon, tungsten, and cobalt, due to the presence of residual oxygen and crystallization water in the initial powders) were $4 \%$ on average, and therefore the electrodes created and the processes associated with them were denoted according to the percentage carbon content before sintering.

The lateral bending strength of sintered electrodes was investigated by a Test Press-250 M. The Rockwell hardness of samples was tested with the aid of a TK2M meter (Russia). It was established that the influence of the carbon percentage on the mechanical properties of the sintered materials (Table 2) was described by the known dependence for WC-Co alloys [10]. The higher tungsten content in electrode no. 1 explains its reduced strength and hardness in comparison to other samples. The low density of the sintered electrodes, with the exception of electrode no. 5, is caused by the high porosity which arose due to the different densities and thermal expansion coefficients of the initial components (WC, W, Co, and C).

\subsection{Coating Deposition}

The substrates employed were $10 \times 10 \times 5 \mathrm{~mm}^{3}$ plates of medium-carbon steel 1035 , while $40 \times 3 \times 3 \mathrm{~mm}^{3}$ rods of sintered $\mathrm{W}-\mathrm{Co}-\mathrm{C}$ were used as the alloying electrodes, that is, the anodes. For electrospark alloying, we used a current pulse generator with a transistor key scheme with a square current pulses shape. Initially, the anode was fixed in the hand vibro-excitor to which current pulses were supplied from the generator. During electrospark processing, the anode oscillated in the "up and down" direction, perpendicular to the cathode surface, and also simultaneously moved along this surface in a zigzag fashion. Discharges arose when electrodes were in contact. The electrospark coatings were formed due to the multiple overlaps of single-discharge spots.

The interelectrode voltage during the pulses was maintained at $40 \mathrm{~V}$. The discharge current amplitude was 100 A, while the frequencies of pulses were 100 and $1000 \mathrm{~Hz}$. The pulse-on duration was $100 \mu \mathrm{s}$, the frequency of the anode vibro-excitor was $100 \mathrm{~Hz}$. The total deposition time for each sample was $5 \mathrm{~min}$ in air. After every $60 \mathrm{~s}$ the deposition process was interrupted and the cathode and

Table 2. Properties of sintered WC-Co-C electrodes.

\begin{tabular}{cccc}
\hline Anode & Density $\left(\mathrm{g} / \mathrm{cm}^{3}\right)$ & Strength $(\mathrm{GPa})$ & Hardness (HRA) \\
\hline $1.5 \mathrm{~A}$ & 6.98 & 0.192 & 77.9 \\
$2.5 \mathrm{~A}$ & 8.57 & 0.301 & 86.9 \\
$3.5 \mathrm{~A}$ & 10.01 & 0.555 & 85.8 \\
$4.5 \mathrm{~A}$ & 11.51 & 0.666 & 86.5 \\
$5.5 \mathrm{~A}$ & 14.00 & 1.477 & 84.2 \\
$8 \mathrm{~A}$ & 10.41 & 0.342 & 74.8 \\
$10 \mathrm{~A}$ & 8.93 & 0.156 & $<50.0$ \\
\hline
\end{tabular}

anode were weighed separately on an electronic balance Vibra HTR-220CE with accuracy up to $10^{-4} \mathrm{~g}$. The microstructure of samples was analysed with the aid of an optical microscope. The microstructure and chemical composition of the coatings were analysed using an optical microscope and an EVO 40HV scanning electron microscope (SEM) (Carl Zeiss, Germany) with an INCA Energy 350 energy-dispersion spectrometer (Oxford Instruments, UK). The phase composition of the produced coatings was examined by a DRON-7 X-ray diffractometer (Burevestnik, Russia) equipped with a $\mathrm{Cu}-\mathrm{K}_{\alpha}$ radiation source in Bragg-Brentano geometry. The microhardness was measured by the Vickers method with a PMT-3M tester (Russia) under a load of $50 \mathrm{~N}$. The abrasive wear resistance of the electrospark coatings was measured by a Calotest friction machine (CSM Instruments, Switzerland) using the "ball-plate" scheme [11]. A ball with a diameter of $30 \mathrm{~mm}$ was rotated at a linear velocity of $0.27 \mathrm{~m} / \mathrm{s}$. Aluminium oxide powder in solar oil was employed as an abrasive material.

\section{Results and Discussion}

\subsection{Properties of Electrodes}

The composition of samples was examined by an X-ray diffractometer DRON-7 (Russia) with $\mathrm{Cu}-\mathrm{K}_{\alpha}$ radiation in Bragg-Brentano geometry. XRD analysis of the prepared electrodes showed that their phase composition was highly dependent on the carbon content (Figure 1). Peaks of tungsten carbide (WC) and tungsten semicarbide $\left(\mathrm{W}_{2} \mathrm{C}\right)$ were observed in the spectra of the $1.5 \mathrm{~A}, 2.5 \mathrm{~A}$, and $3.5 \mathrm{~A}$ electrodes, in which carbon was deficient. The composition of the $5.5 \mathrm{~A}$ electrode was close to the standard hard alloy WC- $10 \%$ Co. For $4.5 \mathrm{~A}$ and $8 \mathrm{~A}$ samples, only the WC carbide was discovered. In the spectra of the $8 \mathrm{~A}$ and $10 \mathrm{~A}$, electrodes that contained more carbon, a carbon peak appeared besides reflections of tungsten carbide.

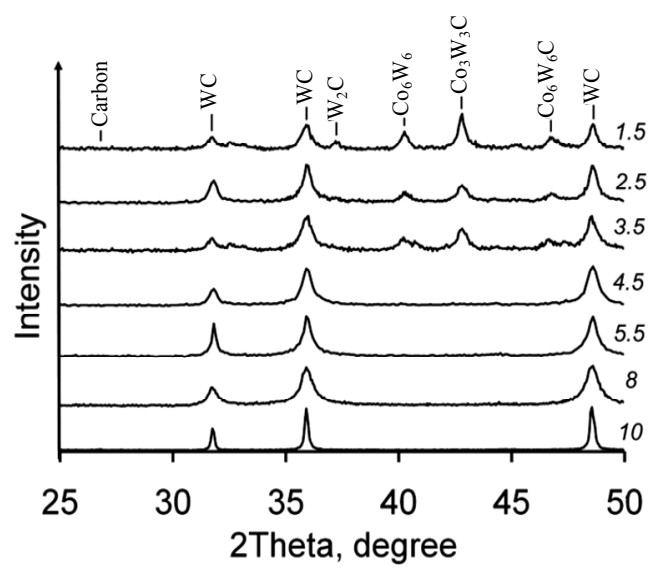

Figure 1. XRD patterns of synthesized electrode materials. 


\subsection{Mass Transfer}

It is typical of electrospark alloying that the masses of both electrodes vary as a consequence of the erosion and the preemptive transfer of metal from the anode onto the cathode. The amount of anode material transferred to the substrate is an important characteristic because it determines the thickness of the deposited coating [1,12]. Our investigations showed that the kinetic curves of the change in electrode mass depended strongly on the carbon concentration of the electrode materials (Figure 2). The maximum cathode gain was $28.6 \mathrm{mg}$ for the $1.5 \mathrm{C}$ sample. The weight gain of the cathode processed with electrode no. 10A was the least and equalled $9.2 \mathrm{mg}$. In addition, it was established that the anode erosion rate was correlated with the strength of the electrode material (Figure 3). With an increase in the anode strength from

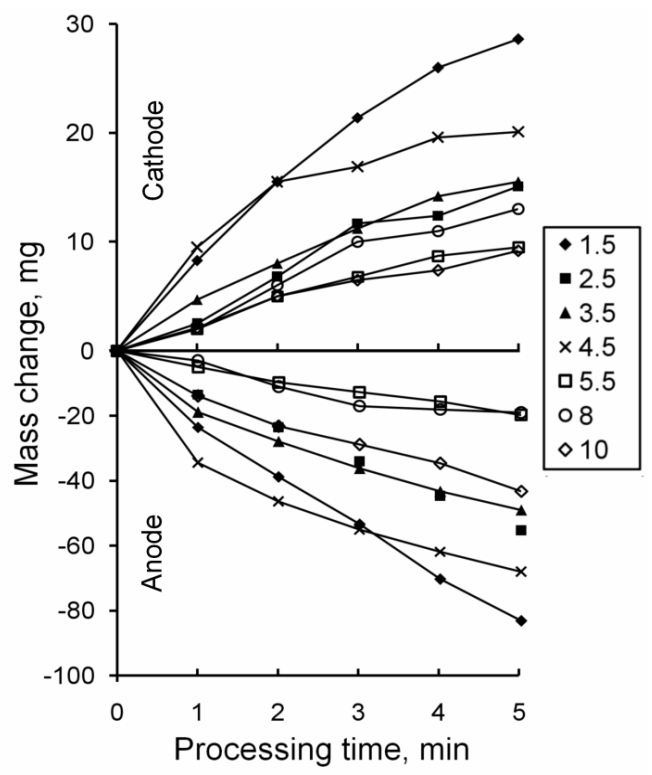

Figure 2. Mass changes of cathodes and anodes with different carbon concentrations.

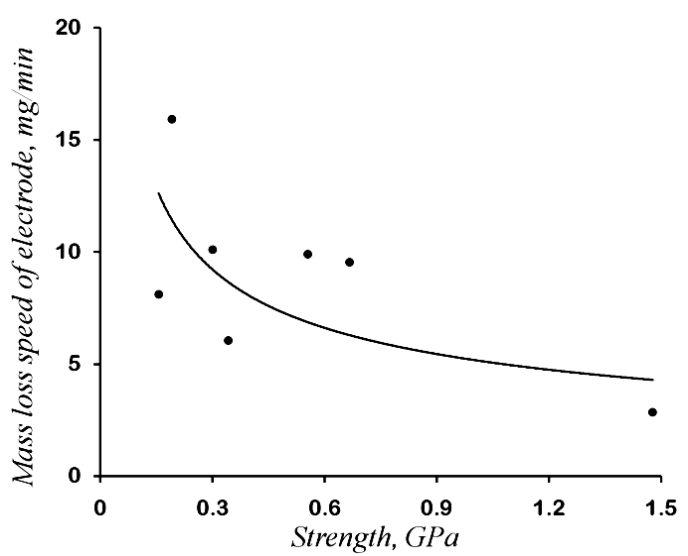

Figure 3. Anode erosion rate as a function of its strength.
0.06 to $1.5 \mathrm{GPa}$, the erosion rate reduced more than 5fold, from 15.9 to $2.8 \mathrm{mg} / \mathrm{min}$. This is because electrodes with low strength are less resistant to thermo-mechanical loads during the discharge process. The greatest strength of $1.477 \mathrm{GPa}$ and the lowest erosion rate of $2.8 \mathrm{mg} / \mathrm{min}$ were attained by the electrode corresponding to the standard WC- $10 \%$ Co with a carbon concentration of 5.5 $\mathrm{wt} \%$.

\subsection{Structure and Composition of Coatings}

The electrospark treatment of steel 1035 by applying the WC-Co-C electrodes was carried out during $5 \mathrm{~min}$ in air with a pulse length of $100 \mu \mathrm{s}$. The investigations showed that the compositions of the obtained coatings were different (Figure 4). When anodes with lower carbon contents $(1.5 \mathrm{~A}, 2.5 \mathrm{~A}, 3.5 \mathrm{~A})$ and a pulse frequency of $100 \mathrm{~Hz}$ were employed, the WC carbide was not detected in the deposited layers, but semicarbide $\mathrm{W}_{2} \mathrm{C}$ was observed, which is indicative of the occurrence of decarburization upon interaction of WC with the iron substrate, which was also observed for electrospark coatings deposition [5] and HVOF spraying [13,14]. On the other hand, when the electrodes with excess carbon $(8 \mathrm{~A}, 10 \mathrm{~A})$ were used, the tungsten carbide WC dominated in the electrospark coatings. Thus, the addition of carbon into the electrode WC- $10 \%$ Co materials allowed the amount of WC phase in deposited layers to increase. The decarburization of hard alloy was intensive at a higher discharge frequency of $1 \mathrm{kHz}$ (Figure 5). The 5.5C coating created at this frequency consisted almost completely of $\mathrm{W}_{2} \mathrm{C}$ together with small amounts of $\mathrm{WC}$ and iron in contrast to the same coating deposited at $100 \mathrm{~Hz}$. When the 10A anode with higher carbon content was used, the WC carbide dominated over semicarbide $\mathrm{W}_{2} \mathrm{C}$ and iron in the coating composition but less so than at the frequency of $100 \mathrm{~Hz}$.

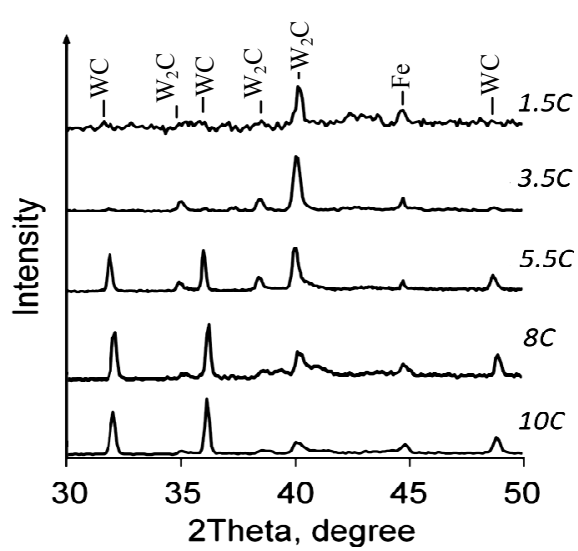

Figure 4. XRD patterns of coatings obtained by the electrospark treatment using electrodes with various carbon concentrations at a frequency of $100 \mathrm{~Hz}$. 


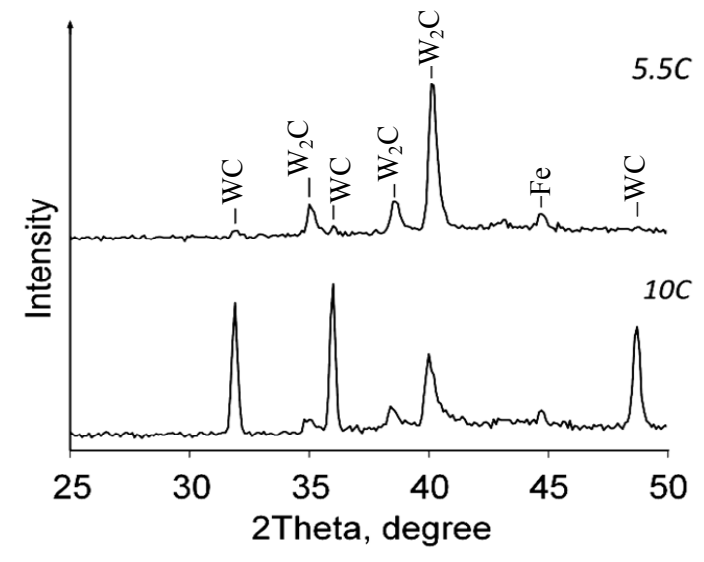

Figure 5. XRD patterns of the coatings obtained by the electrospark treatment with electrodes $5.5 \mathrm{~A}$ and $10 \mathrm{~A}$ at a frequency of $1 \mathrm{kHz}$.

Figure 6 shows cross-sectional images of surface layers of steel 1035 after electrospark alloying with different anode materials. The thickness of the obtained coatings was $33-45 \mu \mathrm{m}$ (Table 3). The $1.5 \mathrm{C}, 2.5 \mathrm{C}$, and $3.5 \mathrm{C}$ coatings were considerably fragmented due to the presence of brittle $\mathrm{W}_{2} \mathrm{C}$ phase that failed under thermo-mechanical loads during discharges. The structure of surface layers deposited by the application of anodes with higher carbon contents was more uniform although there were some micropores. In regions of steel 35 adjoining the interface between the coating and the substrate, a pearlite structure formed because of the short duration of quenching.

SEM images of the surface and cross-sections of the obtained layers show the presence of grains whose elemental composition corresponds to tungsten carbide (WC). Moreover, the amount of these grains is much larger in the $10 \mathrm{C}$ coating than in the $5.5 \mathrm{C}$ one (Figure 7).

EDS data analysis showed that $20-37$ at.\% of iron is present in the obtained coating (Figures 7(c)-(d), Table 3). Its concentration remains practically constant over the cross-section of the layer. The concentration of carbon also does not change along the cross-section of the layer. However, it was established that with increasing carbon content in the electrode, its concentration in the coating increased, since the carbon concentration of the coating of the $10 \mathrm{C}$ sample ranged from 30 to 40 at. $\%$, while that obtained using the standard electrode (5.5C) was $26-31$ at.\%. It is remarkable that on the substrate areas adjacent to the interface (Figures 7(c)-(d), Table 3; points 5,6), the carbon concentration was higher than in the volume of the steel substrates. This may be explained by the diffusion of carbon from the coating to the top layers of the substrate. Thus, the addition of carbon into the electrode materials can increase its content in the coating and prevent decarburization of tungsten carbide due to saturation of the iron present in the coating by additional carbon.

\subsection{Mechanical Properties of Coatings}

One of the advantages of hard alloy coatings is their high wear resistance [15-17] and therefore this characteristic was determined for the obtained electrospark coatings deposited during $5 \mathrm{~min}$ at a frequency of $100 \mathrm{~Hz}$. The wear testing showed that the wear resistance of all cathode surfaces modified by the electrospark treatment with the use WC-Co-C electrodes increased by a factor of four or more in comparison with the steel substrate. Figure 8 shows that $8 \mathrm{C}$ and $10 \mathrm{C}$ coatings have the highest wear resistance. The wear resistance of the $10 \mathrm{C}$ coating obtained at a higher discharge frequency of $1 \mathrm{kHz}$ was seven times higher than that of a conventional $5.5 \mathrm{C}$ sample.

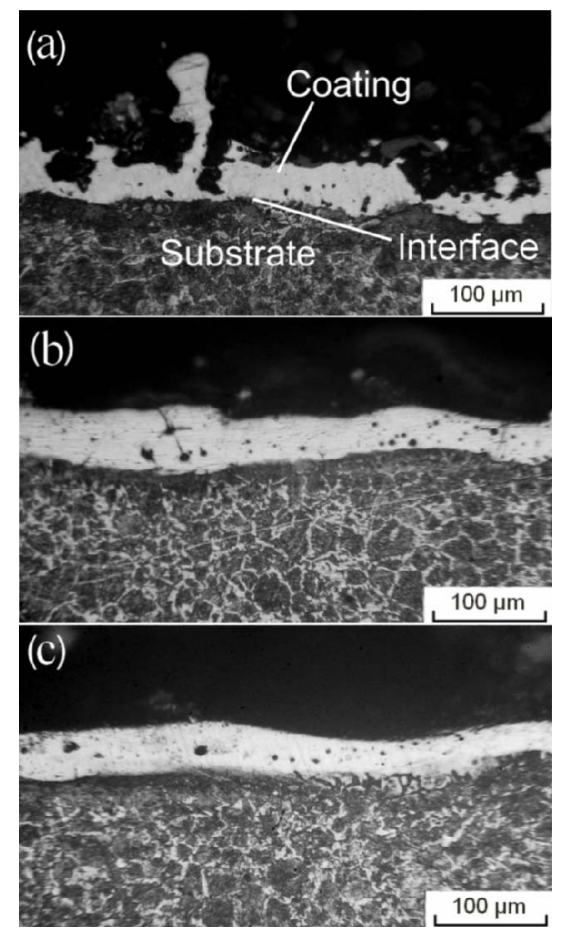

Figure 6. Cross-sectional views of electrospark coatings: (a) 1.5C; (b) 5.5C; (c) 8C.

Table 3. Elemental composition (at.\%) according to EDXS data.

\begin{tabular}{|c|c|c|c|c|c|c|c|c|}
\hline \multirow[t]{2}{*}{ Area } & \multicolumn{4}{|c|}{$\begin{array}{c}\text { Coating deposited with standard } \\
\text { WC- } 10 \% \text { Co (5.5\% carbon) } \\
\text { electrode (Figure 7(c)) }\end{array}$} & \multicolumn{4}{|c|}{$\begin{array}{l}\text { Coating deposited with } \\
\text { WC- } 10 \% \text { Co (10\% carbon) } \\
\text { electrode (Figure 7(d)) }\end{array}$} \\
\hline & $\mathrm{C}$ & W & Co & $\mathrm{Fe}$ & $\mathrm{C}$ & W & Co & $\mathrm{Fe}$ \\
\hline 1 & 31 & 31 & 6 & 32 & 37 & 35 & 7 & 22 \\
\hline 2 & 31 & 32 & 6 & 31 & 35 & 33 & 8 & 25 \\
\hline 3 & 26 & 32 & 8 & 35 & 40 & 34 & 6 & 20 \\
\hline 4 & 31 & 31 & 6 & 32 & 30 & 32 & 5 & 33 \\
\hline 5 & 28 & 31 & 4 & 37 & 30 & 0 & 0 & 70 \\
\hline 6 & 31 & 0 & 0 & 69 & 32 & 0 & 0 & 68 \\
\hline 7 & 24 & 0 & 0 & 76 & 20 & 0 & 0 & 80 \\
\hline 8 & 57 & 37 & 1 & 5 & 46 & 43 & 6 & 5 \\
\hline
\end{tabular}



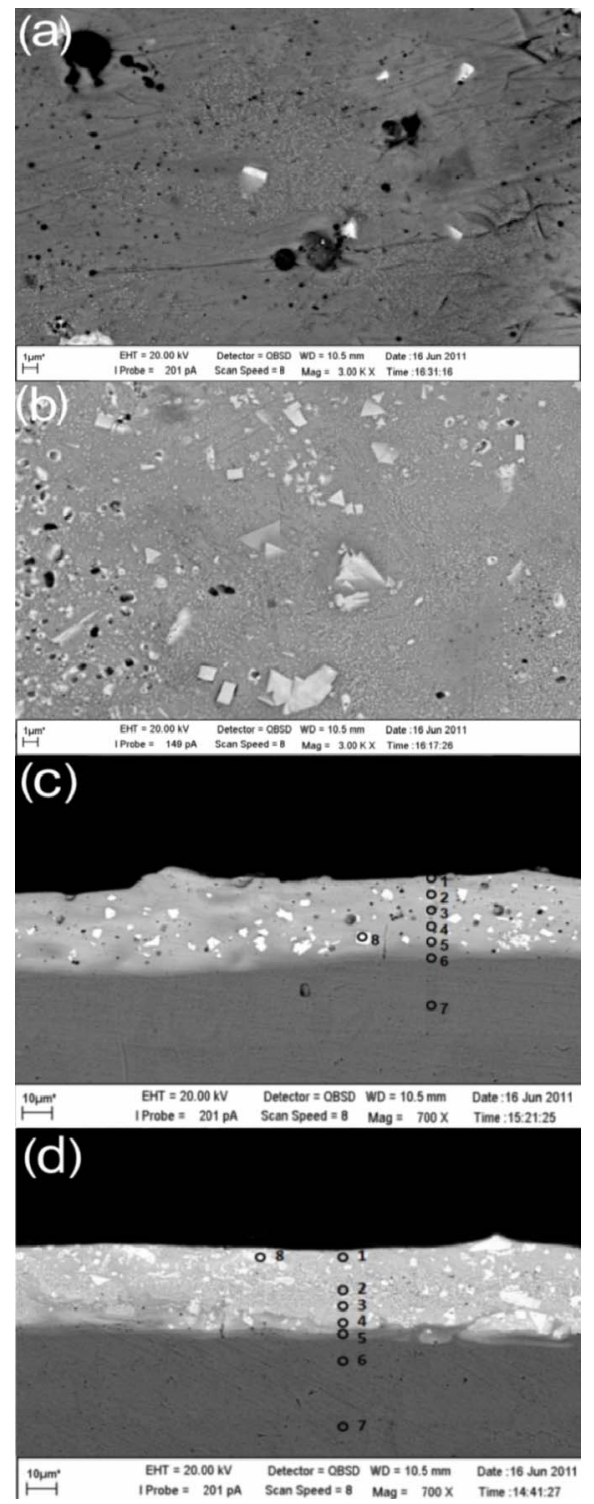

Figure 7. SEM images of the surface (a), (b) and cross-section (c), (d) of the coatings deposited with electrodes containing $5.5 \%$ (a), (c) and $10 \%$ (b), (d) carbon.

Table 4 shows that the average thickness of the coatings varied between 34 to 44 microns. Despite the fact that the gain in weight of the cathodes with $1.5 \mathrm{C}-4.5 \mathrm{C}$ was higher than the $5.5 \mathrm{C}-10 \mathrm{C}$ to almost the same thickness. This can be explained by the higher erosion of the substrate for samples with 5.5C - 10C. The average microhardness of the created coatings is presented in Table 4. It can be seen that modified surface layers have higher microhardness than steel 1035 (2.18 GPa) [18,19]. With increasing carbon content in the anode materials, the microhardness of electrospark coatings deposited with their application decreases. This is explained by the fact that the $\mathrm{W}_{2} \mathrm{C}$ is a harder phase as compared to $\mathrm{WC}$ but is brittle [20].

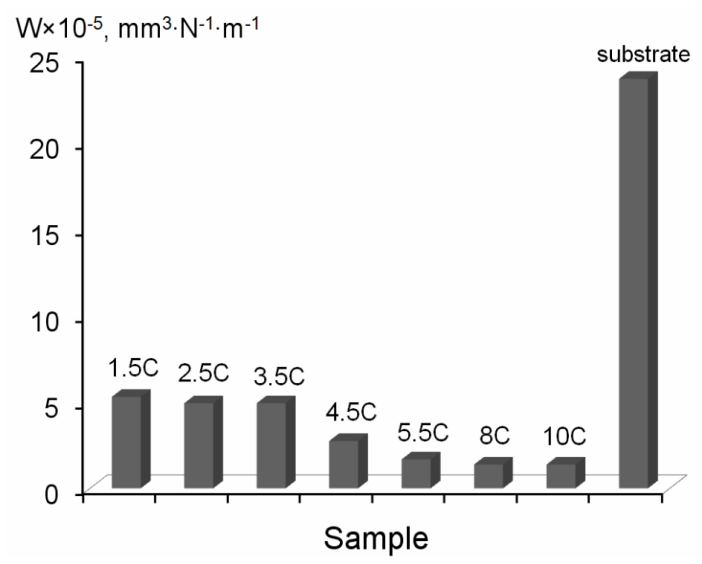

Figure 8. Wear rate of coatings in comparison with steel 35.

Table 4. Average thickness and microhardness of electrospark coatings.

\begin{tabular}{cccccccc}
\hline & \multicolumn{7}{c}{ Cathode } \\
\cline { 2 - 7 } Property & $1.5 \mathrm{C}$ & $2.5 \mathrm{C}$ & $3.5 \mathrm{C}$ & $4.5 \mathrm{C}$ & $5.5 \mathrm{C}$ & $8 \mathrm{C}$ & $10 \mathrm{C}$ \\
\hline $\begin{array}{c}\text { Average } \\
\text { thickness }(\mu \mathrm{m})\end{array}$ & 34 & 44 & 45 & 40 & 35 & 40 & 37 \\
$\begin{array}{c}\text { Average } \\
\text { microhardness } \\
(\mathrm{GPa})\end{array}$ & $18 \pm 4$ & $17 \pm 1$ & $14 \pm 2$ & $15 \pm 1$ & $16 \pm 2$ & $14 \pm 1$ & $14 \pm 2$ \\
\hline
\end{tabular}

\section{Conclusions}

1) Electrode materials with different carbon concentrations were prepared on the basis of $\mathrm{WC}-10 \% \mathrm{Co}$. Electrospark coatings deposited with electrodes on the basis of the WC- $10 \%$ Co with different carbon concentrations onto medium-carbon steel 1035 were found to exhibit a higher WC concentration compared to those deposited with conventional WC-Co electrodes. An increase in carbon concentration in WC-Co-C electrode materials can reduce the decarburization of $\mathrm{WC}$ in electrospark coatings.

2) An increase in carbon concentration in WC-Co-C electrode materials can increased the wear resistance of WC-Co electrospark coatings. The best wear resistance of coatings is obtained with a carbon concentration of 8 $10 \mathrm{wt} \%$ in the electrodes.

\section{REFERENCES}

[1] A.V. Ribalko and O. Sahin, "A Modern Representation of the Behaviour of Electrospark Alloying of Steel by Hard Alloy," Surface and Coatings Technology, Vol. 201, No. 3-4, 2006, pp. 1724-1730. doi:10.1016/j.surfcoat.2006.02.044

[2] J.-S. Wang, H.-M. Meng, H.-Y. Yu, Z.-S. Fan and D.-B. Sun, "Characterization and Wear Behavior of WC-0.8Co Coating on Cast Steel Rolls by Electro-Spark Deposition," International Journal of Minerals, Metallurgy and 
Materials, Vol. 16, No. 6, 2009, pp. 707-713.

[3] E. A. Levashov, E. I. Zamulaeva, A. E. Kudryashov, P. V. Vakaev, M. I. Petrzhik and A. Sanz, "Materials Science and Technological Aspects of Electrospark Deposition of Nanostructured WC-Co Coatings onto Titanium Substrates," Plasma Processes and Polymers, Vol. 4, No. 3, 2007, pp. 293-300. doi:10.1002/ppap.200600148

[4] N. Radek and K. Bartkowiak, "Performance Properties of Electro-Spark Deposited Carbide-Ceramic Coatings Modified by Laser Beam," Physics Procedia, Vol. 5, 2010, pp. 417-423.

[5] E. I. Zamulaeva, E. A. Levashov, A. E. Kudryashov, P. V. Vakaev and M. I. Petrzhik, "Electrospark Coatings Deposited onto an Armco Iron Substrate with Nano- and Microstructured WC-Co Electrodes: Deposition Process, Structure, and Properties," Surface and Coatings Technology, Vol. 202, No. 15, 2008, pp. 3715-3722. doi:10.1016/j.surfcoat.2008.01.008

[6] R. J. Wang, Y. Y. Qian and J. Liu, "Interface Behavior Study of WC92-Co8 Coating Produced by Electrospark Deposition," Applied Surface Science, Vol. 240, No. 1-4, 2005, pp. 42-47. doi:10.1016/j.apsusc.2004.05.299

[7] P. Bague, J. P. Morizot and G. Desgardin, "Evidence for the Phenomenon of Carburization-Decarburization of Tungsten Carbide," Journal of Physics D: Applied Physics, Vol. 27, No. 2, 1994, pp. 402-406. doi:10.1088/0022-3727/27/2/034

[8] S. V. Nikolenko, S. A. Pyachin and A. A. Burkov, "Formation of Electrospark Coatings of the VK8 Hard Alloy with the $\mathrm{Al}_{2} \mathrm{O}_{3}$ Additive," Russian Journal of Non-Ferrous Metals, Vol. 52, No. 1, 2011, pp. 56-61.

[9] V. S. Panov, "Technology and Properties of Sintered Hard Alloys," MISA, Moscow, 2001.

[10] V. I. Tretyakov, "Fundamentals of Physical Metal-Lurgy and Production of Sintered Hard Alloys," Metallurgy, Moscow, 1976.

[11] Y. Kusano, K. V. Acker and I. M. Hutchings, "Methods of Data Analysis for the Micro-Scale Abrasion Test on Coated Substrates," Surface and Coatings Technology, Vol. 183, No. 2-3, 2004, pp. 312-327. doi:10.1016/j.surfcoat.2003.10.010

[12] L. Slatineanu, M. Coteata, A. Goncalves-Coelho, V. Braha,
R. Purcariu and A. Radeanu, "Metallurgical Phenomena at the Surface Alloying and Deposition by Electrical Discharges," Metalurgia International, Vol. 14, 2009, pp. 229-234.

[13] J. M. Guilemany, S. Dosta and J. R. Miguel, "The Enhancement of the Properties of WC-Co HVOF Coatings through the Use of Nanostructured and Microstructured Feedstock Powders," Surface and Coatings Technology, Vol. 201, No. 3-4, 2006, pp. 1180-1190.

doi:10.1016/j.surfcoat.2006.01.041

[14] S. Y. Park, M. C. Kim and C. G. Park, "Mechanical Properties and Microstructure Evolution of the Nano WC-Co Coatings Fabricated by Detonation Gun Spraying with Post Heat Treatment," Materials Science and Engineering: A, Vol. 449-451, 2007, pp. 894-897. doi:10.1016/j.msea.2006.02.444

[15] M. Magnani, P. H. Suegama, N. Espallargas, S. Dosta, C. S. Fugivara, J. M. Guilemany and A. V. Benedetti, "Influence of HVOF Parameters on the Corrosion and Wear Resistance of WC-Co Coatings Sprayed on AA7050 T7," Surface and Coatings Technology, Vol. 202, No. 19, 2008, pp. 4746-4757. doi:10.1016/j.surfcoat.2008.04.055

[16] K. R. C. Soma Raju, N. H. Faisala, D. Srinivasa Raoa, S. V. Joshia and G. Sundararajan, "Electro-Spark Coatings for Enhanced Performance of Twist Drills," Surface and Coatings Technology, Vol. 202, No. 9, 2008, pp. 16361644. doi:10.1016/j.surfcoat.2007.07.084

[17] J. Wang, H. Meng, H. Yu, Z. Fan and D. Sun, "Wear Characteristics of Spheroidal Graphite Roll WC-8Co Coating Produced by Electro-Spark Deposition," Rare Metals, Vol. 29, No. 2, 2010, pp. 174-179. doi:10.1007/s12598-010-0030-6

[18] P. K. Aw and B. H. Tan, "Study of Microstructure, Phase and Microhardness Distribution of HVOF Sprayed MultiModal Structured and Conventional WC-17Co Coatings," Journal of Materials Processing Technology, Vol. 174, No. 1-3, 2006, pp. 305-311. doi:10.1016/j.jmatprotec.2006.02.006

[19] N. Radek, "Determining the Operational Properties of Steel Beaters after Electrospark Deposition," Eksploatacja i Niezawodnosc, No. 4, 2009, pp. 10-16.

[20] G. V. Samsonov, V. K. Vitryanyk and F. I. Chapligin, "Tungsten Carbides," Naukova Dumka, Kiev, 1974. 